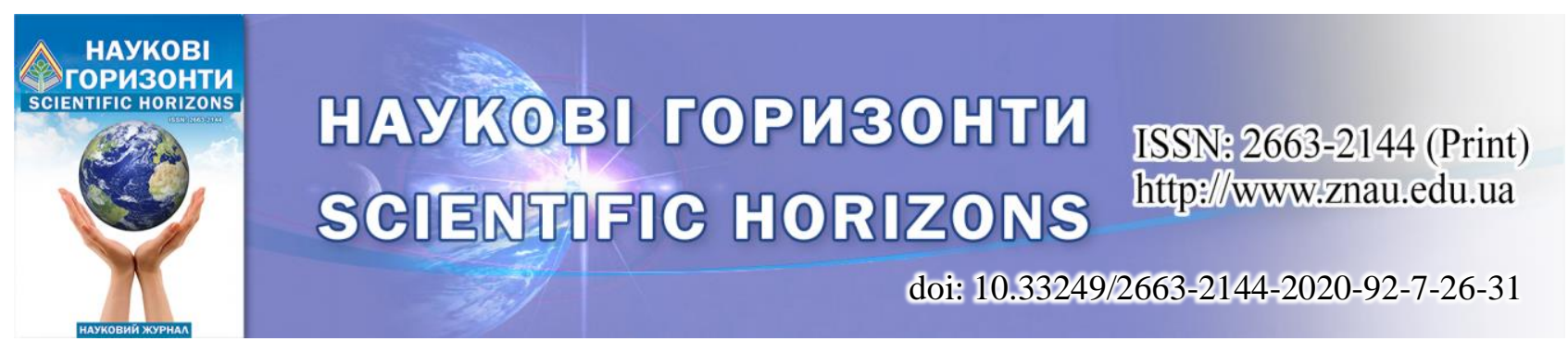

UDC 636:591.4:591.441

\title{
CYTO- AND HISTOMETRY OF RUMINANTIA`S AND HORSES MESENTERIAL LYMPH NODES
}

\section{Horalskyi ${ }^{1}$, O. Dunaievska ${ }^{2}$, N. Kolesnik ${ }^{1}$, I. Sokulskyi ${ }^{1}$, I. Horalska ${ }^{1}$}

Article info

Received

12.05.2020

Accepted

24.06.2020

${ }^{1}$ Zhytomyr

National

Agroecological

University

7, Staryi Blvd,

Zhytomyr, 10008, Ukraine

${ }^{2}$ Zhytomyr

College of

Pharmacy

99, Chudnivska

Str., Zhytomyr,

10005, Ukraine

E-mail:

goralsky@ukr.net; oksana_fd@ukr.net; natacha_kolesnik @ukr.net;

sokulskiy_1979@

ukr.net
Horalskyi, L., Dunaievska, O., Kolesnik, N., Sokulskyi, I., Horalska, I. (2020). Cyto- and histometry of ruminantia's and horses mesenterial lymph nodes. Scientific Horizons, 07 (92), 26-31. doi: 10.33249/2663-2144-2020-92-7-26-31.

Features of histoarchitectonics, cyto- and histometry of mesenteric lymph nodes in ruminants (cattle, sheep) and horses have been clarified. Scientific studies show that the histoarchitectonics of mesenteric lymph nodes in experimental animals are similar but differ in certain morphometric parameters.

Lymph nodes are covered with a connective tissue capsule. Its thickness in cattle 1.7 fold greater than the thickness in sheep and horses. The parenchyma of the lymph nodes is formed by cortical and cerebral substances, the boundary between which is clearly expressed on the section of lymph nodes. According to the analysis of morphometric studies, the cortex is more developed in sheep $(55.14 \pm 16.7 \%)$, the brain in horses $(68.6 \pm 6.83 \%)$. However, the average area of lymph nodes in sheep $\left(0.19 \pm 0.05 \mathrm{~mm}^{2}\right)$ and horses $\left(0.08 \pm 0.01 \mathrm{~mm}^{2}\right)$ is much smaller than in cattle $\left(0.46 \pm 0.07 \mathrm{~mm}^{2}\right)$. The cytostructure of lymph nodes is represented by various cellular elements, the most pronounced of which are blast forms, lymphocytes, reticular cells, macrophages, which differ in their structure and intensity of staining. In the lymph nodes of mesenteric lymph nodes in cattle, small and medium lymphocytes $(47.1 \pm 2.53 \%$ and $31.7 \pm 1.84 \%)$ occupy a significant share. In large numbers, they are located on the periphery of lymph nodes with pronounced light centers. Reticular cells are $14.6 \pm 1.37 \%$. Lymphoblasts and large lymphocytes, which are mainly localized in the light centers of the lymph nodes, occupy $3.8 \pm 0.87 \%$, and macrophages $1.4 \pm 0.3 \%$. The proportion of destroyed cells is $1.0 \pm 0.26 \%$.

The main part of the cerebral substance is occupied by pulp cords. There is a tendency for small lymphocytes to increase, mainly due to a 3.1-fold decrease in the number of blasts and large lymphocytes, a 3-fold decrease in the number of macrophages, and a two-fold decrease in the number of destroyed cells. The number of average lymphocytes and reticular cells is almost unchanged compared to the same indicators in the lymph nodes and is $31.0 \pm 2.48 \%$ and $13.8 \pm 1.5 \%$.

A similar distribution of cellular elements in the lymph nodes and lymph nodes was observed in sheep and horses. However, in sheep, in contrasts to cattle, there was a 1.4-fold increase in the number of blasts and large lymphocytes in the lymph nodes and 1.6-fold in the pulp. In horses, these figures have not changed. An increase in the cytopopulation of reticular cells was observed, especially in pulp cords from $13.8 \pm 1.5 \%$ in cattle to $23.0 \pm 1.73 \%$ in sheep and to $21.1 \pm 0.9 \%$ in horses. The number of macrophages remained almost at the same level as in cattle. The percentage of destroyed cells in ruminants was almost the same, but in horses, this figure increased 1.8 fold in the lymph nodes and decreased 2.5 fold in the pulp, relative to such figures in cattle.

Key words: mesenteric lymph nodes, histometry, ruminants, horses. 


\title{
ЦИТО- ТА ГІСТОМЕТРІЯ МЕЗЕНТЕРІАЛЬНИХ ЛІМФАТИЧНИХ ВУЗЛІВ ЖУЙНИХ ТА КОНЕЙ
}

\author{
Л. П. Горальський ${ }^{1}$ О. Ф. Дунаєвська ${ }^{2}$, Н. Л. Колеснік ${ }^{1}$, І. М. Сокульський ${ }^{1}$, I. Ю. Горальська $^{1}$ \\ ${ }^{1}$ Житомирський національний агроекологічний університет \\ бульвар Старий, 7, м. Житомир, 10008, Україна \\ ${ }^{2}$ Житомирський базовий фармацевтичний фаховий коледж \\ вул. Чуднівська, 99, м. Житомир, 10005, Україна
}

3'ясовано особливості гістоархітектоніки, цито- та гістометрію мезентеріальних лімфатичних вузлів у жуйних (великої рогатої худоби, овеиь) та коней.

Проведені дослідження свідчать, щз гістоархітектоніка мезентеріальних лімфатичних вузлів у дослідних тварин подібна, але різниться певними морфометричними показниками.

Лімфатичні вузли вкриті сполучнотканинною капсулою. Ї̈ у великої рогатої худоби у 1,7 раза є більшою за товщину у овець та коней. Паренхіма лімфатичних вузлів сформована кірковою та мозковою речовинами, межа між якими на зрізі лімфатичних вузлів чітко виражена. Згідно з аналізом

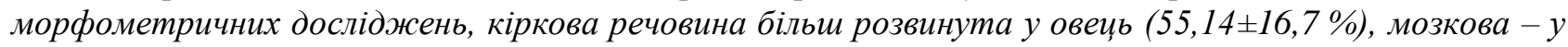
коней $(68,6 \pm 6,83 \%)$. Водночас середня площа лімфатичних вузликів лімфатичних вузлів у овець

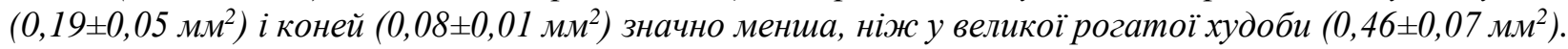

Цитоструктура лімфовузлів представлена різними клітинними елементами, найбільш вираженими серед яких є макрофаги, лімфобласти, лімфоцити, щңо відрізняються своєю будовою та інтенсивністю зафарбування. У лімфатичних вузликах мезентеріальних лімфовузлів великої рогатої

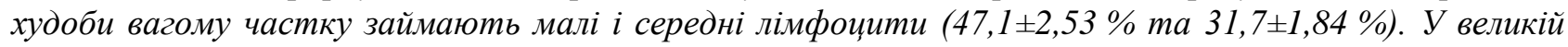
кількості вони розміщуються периферією лімфатичних вузликів з вираженими світлими центрами. Ретикулярні клітини становлять 14,6 $\pm 1,37 \%$. Лімфобласти і великі лімфоцити, які переважно

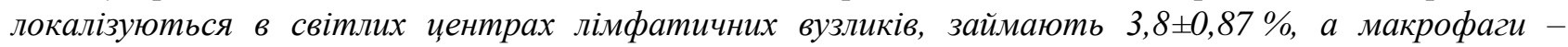

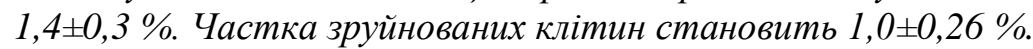

Основну частину мозкової речовини займають м'якушеві тяжі. В них остерігається тенденспиія до збільшення малих лімфоцитів, в основному за рахунок зменшення в 3,1 раза кількості бластів $i$ великих лімфочитів, в 1,3-макрофагів і в два рази зруйнованих клітин. Кількість середніх лімфоцитів і ретикулярних клітин майже не змінюється в порівнянні з такими ж показниками в лімфатичних вузликах і становить $31,0 \pm 2,48 \%$ та 13,8 $1,5 \%$.

Аналогічний розподіл клітинних елементів у лімфатичних вузликах та м'якушевих тяжах лімфатичних вузлів спостерігали і у овеиь та коней. Однак, у овещь щодо великої рогатої худоби, встановили збільшення у 1,4 раза кількості бластів та великих лімфоцитів у лімфатичних вузликах та y 1,6 раза у м'якушевих тяжах. У коней ці показники практично не змінювалися. Спостерігали

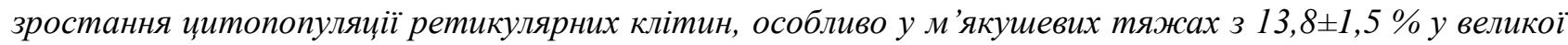

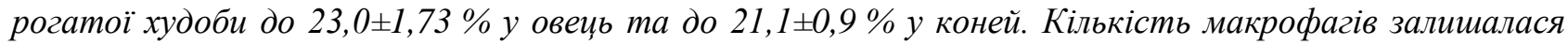
майже на тому ж рівні, що й увеликої рогатої худоби. Процентна частка зруйнованих клітин у жуйних практично була однаковою, однак у коней цей показник більший в 1,8 раза в лімфатичних вузликах і менший в 2,5 раза в м'якушевих тяжах щзодо таких показників у великої рогатої худоби.

Ключові слова: мезентеріальні лімфатичні вузли, гістометрія, жуйні, коні.

\section{Вступ}

Важливе значення у діагностиці захворювань відіграють дослідження лімфатичних вузлів (Litvinov et al., 2012; Mazanniy et al., 2013; Stegney et al., 2014), вагому частку серед яких займають гістологічні (Rudoy et al., 2013) та морфометричні (Gorbatenko \& Shutchenko, 2011) методи. Лімфатичні вузли (ЛВ) належать до вторинних або периферичних органів імунного захисту (Khaksary-Mahabady et al., 2018) та забезпечують бар'єрний захист організму від інфекційних та метастатичних агентів (Nikityuk et al., 2015; Astahova \& Ushakov, 2016; Petrovet et al., 2017). Розробка методів оздоровлення та збереження тварин обов'язково включає обстеження стану лімфовузлів (Grinevich et al., 2014; Litvinetal., 2014). 


\section{Матеріал і методи дослідження}

Робота проводилася на кафедрі анатомії i гістології Поліського національного університету. Об'єктом дослідження були мезентеріальні лімфовузли великої рогатої худоби, овець та коней.

Для гістологічних досліджень шматочки матеріалу, відразу після забою тварин, фіксували у 10-12\%-ому охолодженому розчині нейтрального формаліну та рідині Карнуа, заливали у парафін за схемою (Goralskiy et al., 2019).

Парафінові зрізи, товщина яких не перевищувала 8 мкм, отримували на мікротомі МС-2. Морфологічні дослідження проводили після зафарбовування гістозрізів гематоксиліном й еозином (Panikar, Goralskiyetal., 2015; Goralskiy et al., 2019).

Морфометричні дослідження структурни хелементів тканин проводили методом світлової мікроскопії. Вимірювання мікроструктур виконували за допомою мікроскопів МБІ - 15/2, "Біолам -Ломо", окуляр-мікрометру МОВ - 1-15 методики (Goralskiy et al., 2019).

Співвідношення кіркової та мозкової речовини лімфовузлів обраховували 3 використанням окулярної сітки. Клітини в мікроструктурах лімфовузлів підраховували на гістопрепаратах зафарбованих азур II-еозином. Статистична обробка цифрових даних проводились за методом Монцевичюте - Ерингене. Значення критерію вірогідності визначали за Стьюдентом і рівнем значимості (Р), (Goralskiy et al., 2019).

\section{Результати досліджень та обговорення}

Мезентеріальні лімфатичні вузли удослідних тварин мають овально-видовжену форму. Лежать вони на одному рівні в єдиному сполучнотканинному каркасі. Лімфовузли мають розвинуту капсулу, товщина якої у великої рогатої худоби в 1,7 раза перевищує товщину щодо овець та коней. Від капсули всередину лімфовузлів відходять трабекули, ділянки яких виявляються в кірковій і мозковій речовинах.

Кіркова речовина ЛВ у ВРХ та коней добре розвинена, на гістологічних препаратах іiі площа дорівнює $42,2 \pm 5,2 \%$ та $31,4 \pm 3,9 \%$, у овець вона в 1,3 та 1,8 раза більша $(55,14 \pm 16,7 \%)$.

Діагностичне значення гістологічного вивчення ЛВ належить лімфатичним вузликам, які чутливі до чужорідних агентів. Так, у овець, хворих на лейкоз, відбувається зменшення розмірів лімфатичних вузликів (Grinevichetal., 2014). Будова лімфатичних вузликів подібна 3 лімфоїдними фолікулами селезінки, для кожного виду тварин та вікової категорії характерними $є$ кількість та розміри (Perepechaeva, 2014; Dunaievska, 2019).

За результатами наших гістологічних досліджень округлі або овальні лімфатичні вузлики містяться у кірковій речовині ЛВ. Їх середні площі у овець $\left(0,19 \pm 0,05 \mathrm{mм}^{2}\right)$ та коней $\left(0,08 \pm 0,01\right.$ мм $\left.^{2}\right)$ суттєво менші порівняно 3 великою рогатою худобою $\left(0,46 \pm 0,07 \quad \mathrm{Mм}^{2}\right)$. Розміщені лімфатичні вузлики переважно в один ряд на периферії кіркової речовини. Але часто у ВРХ містяться вони у кілька рядів, у глибині кіркової речовини, але завжди поблизу трабекул. В окремих випадках лімфатичні вузлики щільно прилягають до капсули, здавлюючи простір підкапсулярних синусів.

Реактивні центри лімфатичних вузликів дослідних тварин займають значну частину, вони відмічаються майже у кожному вузлику. Дослідженнями реактивних центрів вже встановлено, що у ранньому постнатальному періоді онтогенезу вони наявні далеко не у всіх вузликах, їх поява зростає з віком тварин та антигенним навантаженням на організм (Perepechaeva, 2014).

М'якушеві тяжі мезентеріальних лімфовузлів неширокі, але центральні синуси великого діаметру i, як правило, мають безпосередне прилягання до трабекул. Наші результати дослідження не суперечать дослідженням інших науковців (Perepechaeva, 2014), яка виявляла м'якушеві тяжі характеризує як мобільний компартмент.

Артеріальні муфти лімфовузлів в основному складаються із лімфоцитів. За напрямком вен, периваскулярна тканина представлена прошарками пухкої сполучної тканини, яка містить велику кількість плазмоцитів i гістіоцитів.

Артеріоли і венули в мозковій речовині досить численні, а судинна зона мозкової речовини являє своєрідну ділянку, яка прилягає до воріт лімфовузлів.

Цитологічний склад ЛВ різний: бластні форми, лімфоцити, ретикулярні клітини та макрофаги, які диференціюються за особливостями морфологічної будови та інтенсивністю забарвлення, що було описано й іншими авторами (Gorbatenko \& Shutchenko, 2011). 


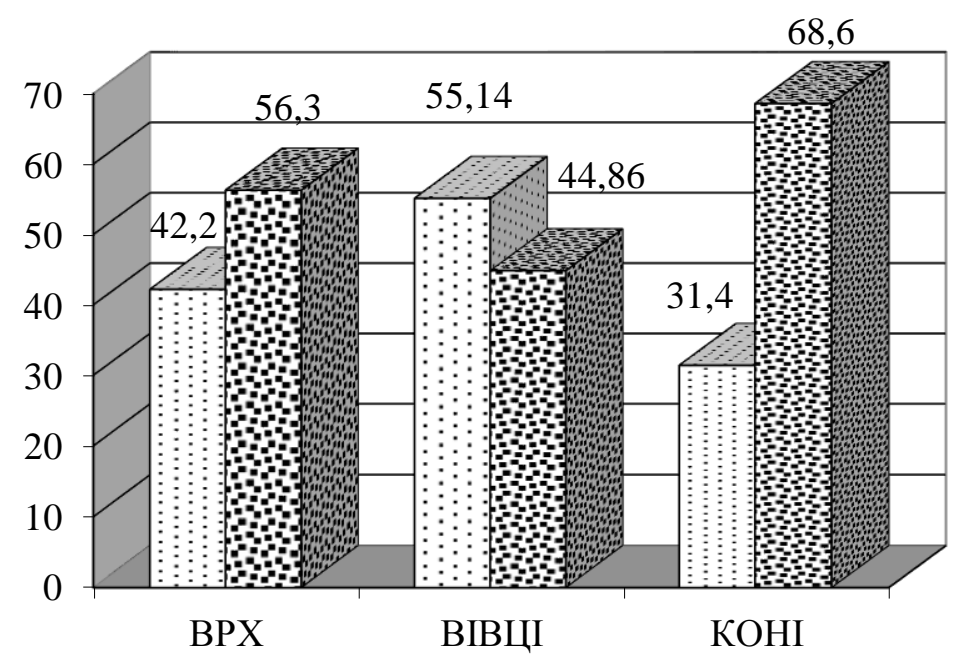

ФПлоща кіркової речовини (\%) Млоща мозкової речовини (\%)

\section{Рис. 1. Морфометричні показники гістоструктур лімфатичних вузлів у сільськогосподарських тварин}

Значно більші розміри мають лімфобласти, в яких слабо розвинена цитоплазма; великої округлої або овальної форми ядро містить 1-2 великих нуклеоли i ніжну сітку хроматину. Лімфобласти при певних умовах мають властивість міняти свою форму. Водночас міняється форма ядра, збільшуються розміри цитоплазми, клітина нагадує моноцит, але 3 бластною структурою ядра. Великі лімфоцити $\epsilon$ перехідними формами лімфобластів до середніх і малих лімфоцитів. Малі лімфоцити мають округле, інтенсивно забарвлене ядро і вузьку, у вигляді обідка, цитоплазму. Макрофагам властиві різноманітні форми 3 бобовидним ядром. Ретикулярні клітини часто видовженої форми, 3 більш пухкою структурою ядерного хроматину, ніж у лімфоцитів.

Згідно 3 проведеним нами цитометричним аналізом, найбільша клітинна популяція лімфатичних вузликів і м'якушевих тяжів ЛВ - це малі лімфоцити. Найбільше, серед дослідних тварин, виявлено у лімфатичних вузликах ЛВ BPX $(47,1 \pm 2,53 \%), \quad$ найменше - у коней $(42,5 \pm 2,5 \%)$. Вагому частку мають середні лімфоцити: у ВРX $-31,7 \pm 1,8 \%$, овець $-29,1 \pm$ $2,3 \%$, коней $-30,4 \pm 2,23 \%$ та ретикулярні клітини $14,6 \pm 1,37 \%, 16,7 \pm 2,2 \%$ та $18,9 \pm 1,8 \%$, відповідно (рис. 2)

У великій кількості малі та середні лімфоцити розміщуються на периферії лімфатичних вузликів 3 вираженими світлими центрами. Відносна частка макрофагів, бластів, великих лімфоцитів незначна, рідко перевищує 5 \% (див. рис. 2).

Основну частину мозкової речовини займають м'якушеві тяжі. За результатами цитометрії у м'якушевих тяжах лімфатичних вузлів ВРХ спостерігається тенденція до збільшення малих лімфоцитів, в основному за рахунок зменшення в 3,1 раза кількості бластів i великих лімфоцитів, в 1,3 - макрофагів і в два рази зруйнованих клітин (рис. 3). Кількість середніх лімфоцитів і ретикулярних клітин тяжів суттєво не відрізняється від кількості в лімфатичних вузликах (рис. 3). Аналогічний розподіл клітин у м'якушевих тяжах ЛВ спостерігали і у овець та коней. Однак, у овець, у порівнянні з ВРХ, встановили збільшення у 1,6 раза кількості бластів та великих лімфоцитів. У коней ці показники практично не змінювалися. Спостерігали зростання цитопопуляції ретикулярних клітин $3 \quad 13,8 \pm 1,5 \%$ у $\mathrm{BPX}$ до $23,0 \pm 1,73 \%$ у овець та до $21,1 \pm 0,9 \%$ у коней (рис. 3). Кількість макрофагів залишалася майже на тому ж рівні, що й у ВРХ (рис. 3). Процентна частка зруйнованих клітин у жуйних практично була однаковою, однак у коней цей показник зменшився в 2,5 раза, щодо таких показників у ВРX (див. рис. 3). 


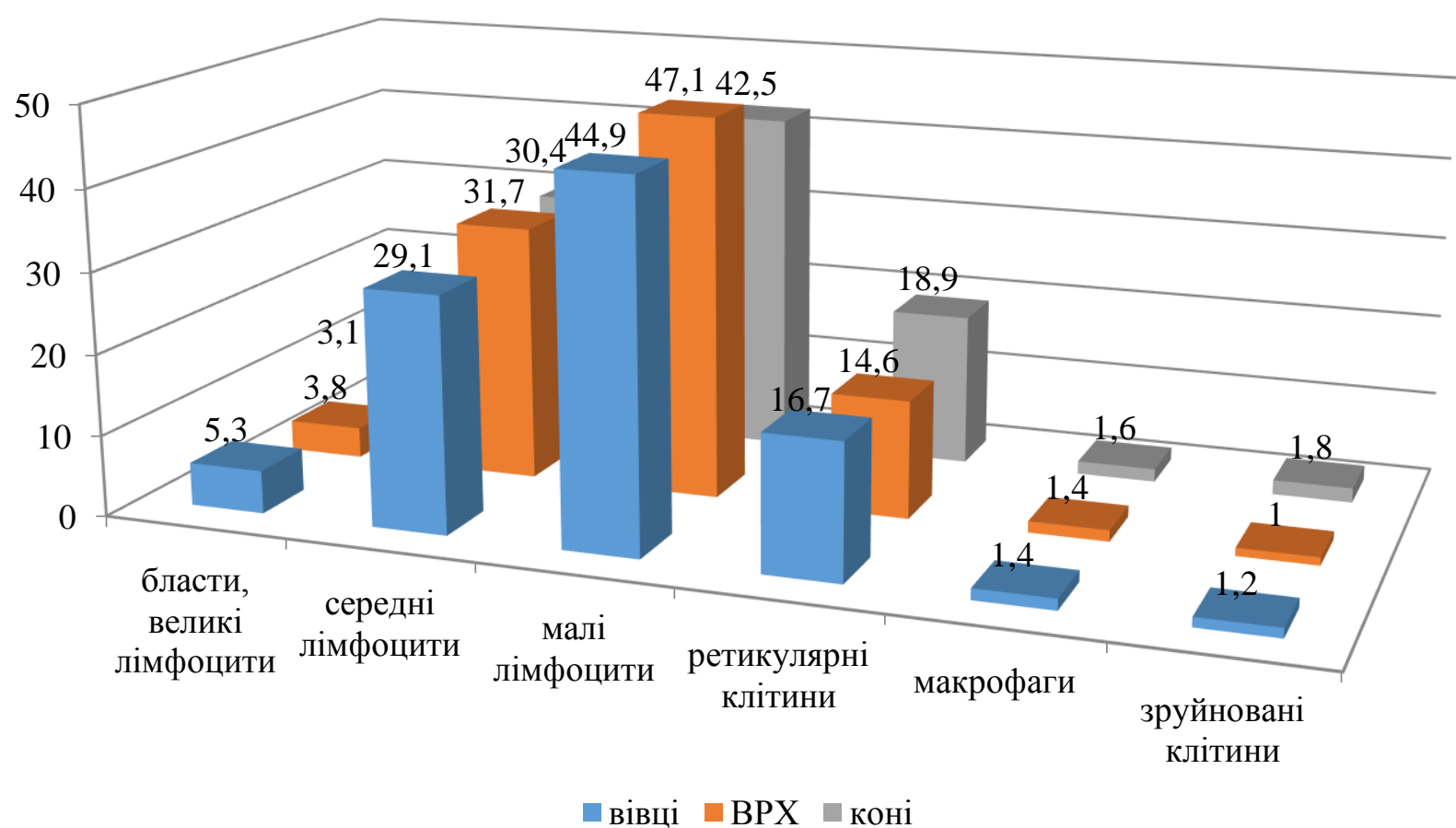

Рис. 2. Вміст клітинних елементів в лімфатичних вузликах лімфовузлів у сільськогосподарських тварин (\%)

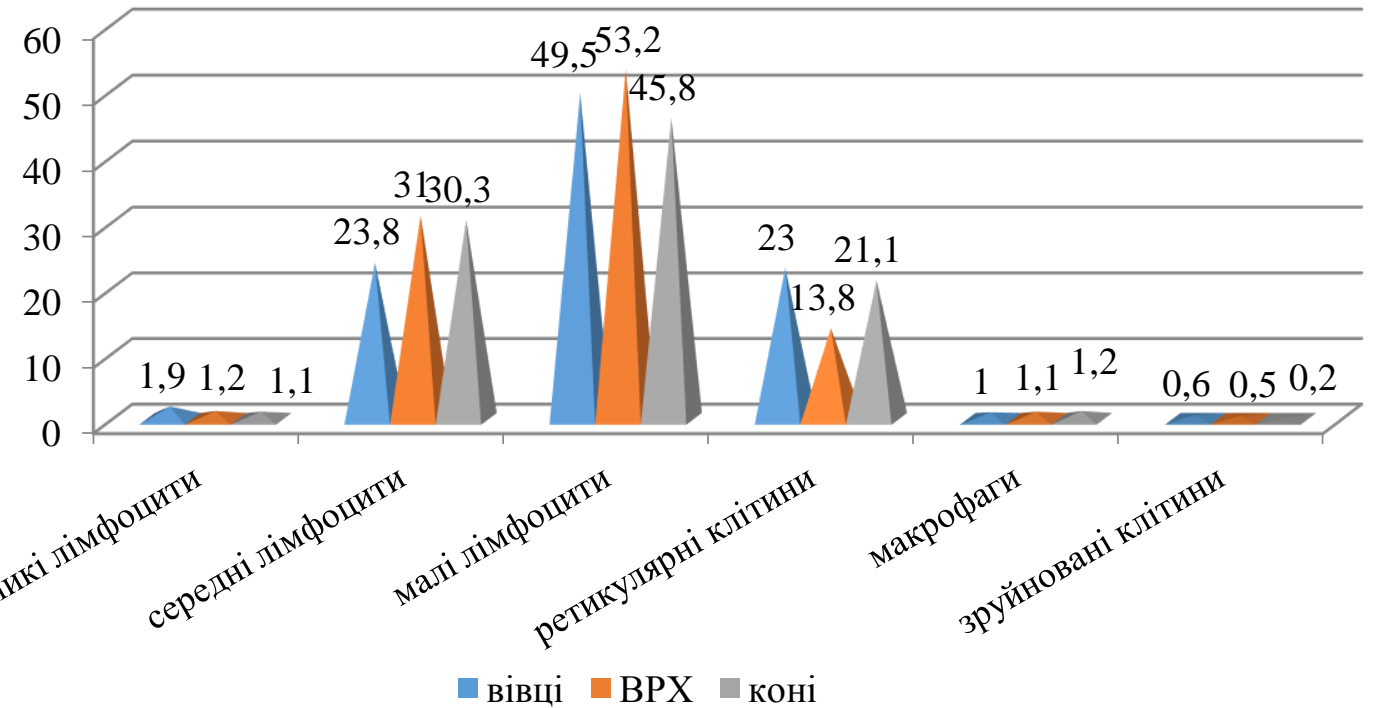

Рис. 3. Вміст клітинних елементів в м'якушевих тяжах лімфовузлів у сільськогосподарських тварин (\%)

\section{Висновки}

1. Мікроскопічна будова мезентеріальних лімфовузлів у жуйних та коней, має подібну гістоархітектоніку, але різниться гісто- та цитометричними показниками:

- кіркова речовина лімфатичних вузлів найбільше розвинена у овець $(55,14 \pm 16,7 \%)$, у великої рогатої худоби та коней ії відносна площа дорівнює 42,2 $\pm 5,2$ та $31,4 \pm 3,9 \%$, відповідно;

- відносна площа мозкової речовини,

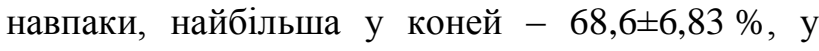
овець менша в 1,5 раза $(44,86 \pm 20,1 \%)$.

2. Цитопопуляція лімфовузлів різноманітна: 
лімфоцити (малі, середні, великі), ретикулярні клітини, бластні форми, і макрофаги. Найбільше було виявлено малих лімфоцитів (від 42,5 $\pm 2,5 \%$ до $47,1 \pm 2,53 \%)$.

\section{References}

Astakhova, I. F. \& Ushakov, S. A. (2016). Model i algoritm iskusstvennoy immunnoy sistemy [Model and algorithm of an artificial immune system]. Matematicheskoye modelirovaniye, 12 (28), 63-73. [in Russian].

Dunaievska, O. F. (2019). Anatomichna kharakterystyka selezinky Bos taurus taurus L. [Anatomical characteristics of the spleen Bos taurus taurus L.]. Visnyk problem biolohii i medytsyny, 1 (1), 265-268. doi: 10.29254/2077-4214-2019-1-1-148265-268 [in Ukrainian].

Horalskyi, L. P., Khomych, V. T. \& Kononskyi, O. I. (2019). Osnovy histolohichnoi tekhniky i morfofunktsionalni metody doslidzhen u normi ta pry patolohii [Fundamentals of histological technique and morphofunctional research methods in normal and pathology]. Zhytomyr : Polissia [in Ukrainian].

Horbatenko, V. P. \& Shutchenko, P. O. (2011). Otsinka imunosupresyvnoho stanu pry klinichnomu limfo leikozi za morfo metrychnymy zminamy limfatychnykh vuzliv [Evaluation of the immunosuppressive state in clinical lymphocytic leukemia by morphometric changes of lymph nodes]. Veterynarna medytsyna, 95, 286-288 [in Ukrainian].

Hrynevych, O. Y., Krasnikov, H. A., Horbatenko, S. K., Shutchenko, P. O., Medvid, K. O., Shapovalova, O. V. ... Kornieikova, O. M. (2014). Doslidzhennia vplyvu preparatu ZG-2011 na imunnu systemu ovets za morfolohichnymy pokaznykamy orhaniv imunnoho zakhystu [Study of the effect of the drug ZG-2011 on the immune system of sheep on the morphological parameters of the immune system]. Veterynarna medytsyna, 99, 193-196 [in Ukrainian].

Khaksary-Mahabady, M., Khazaeel, K., Borujeni, M. P. \& Yazdanjoo, B. (2018). Morphometric development of sheep (Ovis aries) lymph nodes in fetal period. Vet Res Forum, 9 (2), 121-128. doi: 10.30466/VRF.2018.30833.

Litvinov, V. F., Krasochko, T. A. \& Karasyov, N. F. (2012). Parazitologicheskiy monitoring dikikh mlekopitayushchikh $\mathrm{v}$ Belarusi. [Parasitological monitoring of wild mammals in Belarus]. Sovremennyye problemy prirodopolzovaniya. okhotovedeniya $i$ zverovodstva, 1, 358-359. [in Russian].

Lytvyn, V. L., Vlasenko, V. V. \& Berezovskyi, I. V.
(2014). Shliakhy ozdorovlennia i zberezhennia tvarynnytstva $\mathrm{v}$ Ukraini [Ways to improve and preserve livestock in Ukraine]. Veterynarna medytsyna Ukrainy, 5 (219), 8-12 [in Ukrainian].

Mazannyi, O. V., Prykhodko, Yu. O. \& Byrka, V. I. (2013). Babezioz ovets u stepovii zoni Skhodu Ukrainy [Babesiosis of sheep in the steppe zone of Eastern Ukraine]. Naukovi pratsi Pivdennoho filialu Natsionalnoho universytetu bioresursiv $i$ pryrodokorystuvannia Ukrainy "Krymskyi ahrotekhnolohichnyi universytet". Ser. Veterynarni nauky, 155, 157-162 [in Ukrainian].

Nikityuk, D. B., Klochkova, S. V. Alekseyeva, N. T. (2015). Sovremennyye predstavleniya ob obshchikh zakonomernostyakh makro-mikroskopicheskoy anatomii limfoidnykh organov [Modern ideas about the general laws of macroscopic anatomy of lymphoid organs]. Zhurnal anatomii i gistopatologii, 4 (2), 9-13 [in Russian].

Panikar, I. I., Horalskyi, L. P., Dunaievska, O. F., Horalska, I. Yu., Sokulskyi, I. M., Pinskyi, O. V. \& Prasolov, Ye. Ya. (2015). Patent Ukrainy 100223 [Patent of Ukraine 100223]. Kyiv : Derzhavne patentne vidomstvo Ukrainy [in Ukrainian].

Perepechaieva, N. H. (2014). Zakonomirnosti strukturno-funktsionalnoi spetsializatsii limfatychnykh vuzliv u velykoi rohatoi khudoby $\mathrm{v}$ rannomu postnatalnomu ontohenezi [Regularities of structural and functional specialization of lymph nodes in cattle in early postnatal ontogenesis]. Naukovo-tekhnichnyi biuleten NDTs biobezpeky ta ekolohichnoho kontroliu resursiv APK, 2 (3), 17-25 [in Ukrainian].

Petrov, R. V., Khaitov, R. M. \& Chereshnev, V. A. (2017). Fiziologiya immunnoy sistemy: kletochnyye i molekulyarno-biologicheskiye mekhanizmy [Physiology of the immune system: cellular and molecular biological mechanisms]. Vestnik Rossiyskogo fonda fundamentalnykh issledovaniy, 1 , 96-119. doi: 10.22204/2410-4639-2017-094-02S96-119. [in Russian].

Rudoi, O. V., Ryzhenko, V. P. \& Papchenko, I. V. (2013). Histolohichnyi metod dyferentsiinoi diahnostyky aktynobatsylozu velykoi rohatoi khudoby [Histological method of differential diagnosis of bovine actinobacillus]. Veterynarna biotekhnolohiia, 23, 456-463 [in Ukrainian].

Stehnei. B. T., Obukhovska, O. V. \& Hliebova, K. V. (2014). Diahnostka i profilaktyka infektsiinoi ahalaktii ovets i kiz [Diagnosis and prevention of infectious agalactia in sheep and goats]. Veterynarna medytsyna Ukrainy, 2 (216), 20-23 [in Ukrainian]. 